\section{Refleksiivisyys ja etnografisesti tuotettu tieto}

Jeremy Gould \& Katja Uusihakala (toim.) (2016). Tutkija peilin edessä. Refleksiivisyys ja etnografinen tieto. Gaudeamus: Helsinki. 254 sivua. ISBN 978-952-495-381-8

"REFLEKTOINTI NOSTAA ESIIN kysymyksiä siitä, miten data syntyy ja mikä on tutkijaminän osa tässä prosessissa." (s. 11.)

Lienee aika ainutlaatuista, että nuorten suomalaisten tutkijoiden tutkimuksista eri puolilla maailmaa saadaan koottua niin monipuolisesti yhtä tutkimuksellista lähestymistapaa valaiseva kirja kuin Tutkija peilin edessä on. Kaikkia siinä kuvattuja tutkimuksia yhdistää tiedonkeruun menetelmä, tai pitäisikö sanoa tiedontuotannon muoto, kuten kirjassa asia useimmiten ilmaistaan.

Kirja koostuu seitsemän etnografisen tutkimuksen kuvauksesta. Ne ovat konkreettisia ja paikoin yksityiskohtaisiakin, mutta kussakin tärkeintä ovat pohdinnat etnografisesti tuotetun tiedon ehdoista ja mahdollisuuksista sekä prosessiin lähes väistämättä kuuluvista vaikeuksista.

Toimittajat katsovat, että "episteemisesti radikaalina tiedontuotannon keinona etnografinen refleksiivisyys voi [- - ] tarjota välineitä paitsi avoimemmalle tiedontuotannolle myös yhteiskunnallisesti kriittiselle ajattelulle." (s. 228.)

\section{TUTKIJA TUTKIMUSVÄLINEENÄ}

Millaista aineistoa syntyy, kun kaksi toisilleen vierasta ihmistä tapaa yhden kerran tunnin ajan, ja toinen pyytää tutkijan arvovallalla toista puhumaan annetusta aiheesta? Kysymys nousee väistämättä mieleen, kun lukee etnografisen tutkimuksen tekijöiden kokemuksia kenttätyöstä.

Esimerkiksi aikuiskasvatustutkimuksessa haastattelu on paljon käytetty tiedonkeruumenetelmä, mutta sen rajoitusten ja ehtojen rekflektointi jää usein vähäiseksi. Kirjassa on runsaasti kuvauksia vuorovaikutukselle rakentuvan aineistonhankinnan vaikeuksista. Pääsy tutkittavan elämään ja hänen näkökulmansa ymmärtäminen edellyttää tutkijalta aikaa vievää läsnäoloa, osallistumista ja vuorovaikutusta.

Tutkimuksen alkuvaiheessa kenttätyön tekijä usein tekee vääriä tulkintoja haastatellessaan tutkimuskohteitaan. Vasta vähitellen hän alkaa ymmärtää tutkittaviensa ajattelua, toimintaa ja valintoja sekä niiden perusteluja. Kuten kirjan toimittajat loppuluvussa toteavat, kaikkia tapaustarkasteluja yhdistää tutkijoiden kuvaama hämmennys ristiriitaisten tarinoiden ja tapahtumien keskellä.

Ihmisten todellisuuksia ja niissä tehtyjä valintoja usein on vaikea ymmärtää. Tiedonmuodostus vaatii joskus pitkäaikaista osallistumista informanttien elämään, mikä koettelee tutkijan uskoa ja jaksamista. Toisinaan osallistuminen

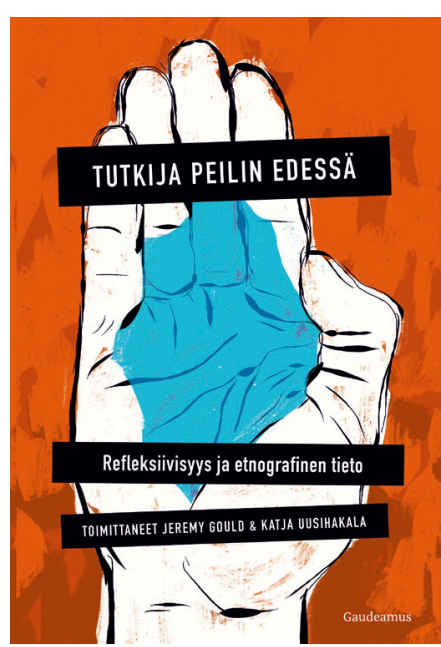

vie laittomiin toimiin ja vaarallisiin tilanteisiin. Lukijalle välittyvät hyvin kokemukset siitä, että "epävarmuus, pelko ja paranoiakin ovat luonnollisia tunteita uudessa ja vieraassa ympäristössä. Paineet ammatillisesta pätemisestä vain lisäävät tutkijan hämminkiä.” (s. 220.)

Kunnollisen aineiston hankkiminen edellyttää tutkijan position ja osapuolten vuorovaikutussuhteen kriittistä reflektointia. Haastattelija ei ole koskaan "yleisihminen" tekemässä haastattelua jossakin "yleisessä paikassa", mitä Gould havainnollistaa analogialla (s. 26): "Vertauskuvallisesti sanottuna kutakin tutkijaa on omien erityispiirteiden ja henkilöhistorian kautta eri tavalla viritelty (kalibroitu) ottamaan vastaan ja käsittelemään määrätynlaisia aistihavaintoja. Avaruustutkimuksessa käytetyt luotaimet on kalibroitu rekisteröimään vain tiettyjä valoaaltoja tai törmäyksiä vain tietynlaisiin partikkeleihin. Vastaavasti tutkijan kognitiivinen apparaatti on rodun, sukupuolen, iän ja luokka-aseman mutta ennen kaikkea kulttuurin, 
kasvatuksen ja omien kokemusten perusteella luonnostaan viritelty huomioimaan (tai olemaan huomioimatta) tietynlaisia signaaleja."

Aineiston tuottamista ei rajoita vain tutkijan kognitiivinen apparaatti, vaan tutkijan ominaisuudet vaikuttavat olennaisesti siihen, millaisia signaaleja tutkittava kohde hänelle lähettää. Kohde myös arvioi sitä, millaista tietoa tutkija kykenee ottamaan vastaan ja ymmärtämään sekä mistä hänelle kannattaa kertoa ja miten.

Sosiaalista vuorovaikutusta ja toimintaa kuvataan aina jostakin positiosta ja näkökulmasta käsin. Havaintoon ja sen tulkintaan vaikuttavat havainnoijan ominaisuudet sekä suhde havaittavaan tapahtumaan ja toimijoihin.

Refleksiivisyys rakentuu tutkijan oman position analyyttisestä kartoittamisesta ja etenee perspektiivin seuraamusten erittelyyn tiedonmuodostuksen näkökulmasta. "Refleksiivisyys on sovellus, joka on pidettävä tutkijaminän episteemisissä laitteissa aina päällä”, Gould kirjoittaa (s. 25).

\section{REFLEKSIIVINEN}

\section{YHTEISKUNTATIEDE}

Kirjan tehtävänä on "avata refleksiivisyyden käsitettä etnografiasta ja laajemminkin laadullisesta yhteiskuntatutkimuksesta kiinnostuneelle lukijalle" sekä "tarkentaa refleksiivisyyden paikkaa ja merkitystä yhteiskuntatieteellisessä tiedon tuotannossa." (s. 9.)

Kirja ei ole metodiopas, vaan se koettaa todellisten tapausten avulla näyttää etnografit työssään ja reflektoimassa tekemistään. Kirjassa puhutaan usein tutkimuksenteon henkilökohtaisuudesta ja tutkijan asennoitumisesta kohteeseen.

Kirjan ensimmäisessä luvussa Gould muun muassa jäljittää refleksiivisyyden juuria ja kehkeytymistä, hahmottelee etnografisen refleksiivisyyden määritelmää sekä tarkastelee refleksiivisyyttä osana sosiaalitieteiden postmodernia käännettä ja keskustelua tiedosta, asiantuntijuudesta ja tietovallasta. Lisäksi hän pohtii refleksiivisyyden rajoja. Luku on erinomainen johdatus aiheeseen.

Gould muotoilee teoksen teesin seuraavasti: "Refleksiivisyys ilmentää alati palavaa, aina keskeneräistä ja siksi radikaalia pyrkimystä luoda yhteiskuntatieteelliselle tiedonmuodostukselle juuri sille ominaista tietoteoreettista perustaa." (s. 14.)

Pyrkimys ankkuroida yhteiskuntatieteellistä tiedonmuodostusta refleksiivisyyteen on kuulunut sosiaalitieteelliseen metodikeskusteluun modernin yhteiskuntatieteen syntymästä lähtien. Gouldin mukaan pyrkiminen refleksiivisyyteen on yritys käsitellä yhteiskuntatieteellisen tiedon perustavaa epävarmuutta ja panna epäilemään uskoa varmaan tietämiseen.

Kirja edustaakin vahvasti kantaa, jonka mukaan refleksiivisyyden tulisi olla kaiken sosiaalitieteellisen tiedonmuodostuksen yleinen hyve. Se ei rajaudu vain laadulliseen aineistonkeruuseen kentällä. Käytännössä etnografinen refleksiivisyys riippuu olennaisesti tutkijasta ja on sillä tavoin perimmältään henkilökohtaista, mikä on yksi peruste kutsua etnografiaa epistemologisesti radikaaliksi yhteiskuntatieteeksi.

Refleksiivisyys ilmestyi sosiaalitieteisiin 1970-luvulla syntyneen postmodernistisen kritiikin myötä. Antropologien etnografisen tutkimuksen kritiikki kytkeytyi myös sen koloniaaliseen perinteeseen. Tuolloin kritiikkiin innoittivat havainnot sosiaalitieteiden epistemologisesta vallankäytöstä.

Refleksiivisyyden esiinnousu ei ollut pelkästään reaktio postmodernismin nostattamaan kritiikkiin, vaan sen juuret ovat syvällä sosiaalitieteiden epistemologisissa kiistoissa. Refleksiivisyys juontuu yhteiskuntatieteiden pyrkimyksestä itsenäistyä luonnontieteen tiedeihanteesta.

Tutkija on osa kohdettaan eli yhteiskunnallista todellisuutta. Hän analysoi, tulkitsee ja kirjoittaa kielellä, jota tutkimuskohteen toimijat käyttävät todellisuuden ja toimintansa ymmärtämiseen, mikä on merkittävä ero luonnontieteisiin verrattuna.

Kirjassa ei ole tarkoitus muotoilla sääntöjä refleksiivisyyden toteuttamisesta vaan pikemminkin näyttää esimerkkitapausten avulla, miten homma toimii. Kuten etnografisen tutkimuksen teko tulkintoineen, refleksiivisyyskin on lopulta sillä tavalla henkilökohtainen asia, että se saa lopullisen muotonsa tutkijan ominaisuuksista.

\section{TUTKIMUS VUORO- VAIKUTUKSEN TULOKSENA}

Kun tähtitieteilijä katsoo kaukoputkella taivaalle, tähdet, planeetat 
ja kuut eivät muuta muotoaan ja koostumustaan sen perusteella, miltä kaukoputki näyttää. Vuorovaikutukseen perustuvissa ihmistieteissä asia on toisin. Tutkija ei voi esimerkiksi haastattelutilanteessa häivyttää kehollisuuttaan mihinkään. Ulkoista habitustaan hän voi jossain määrin muokata.

Tutkimusaineistoa kerätessään tutkija on itsekin kohde, tutkimuskohteensa kohde. Tutkija herättää tutkittavissaan monenlaisia odotuksia, mielikuvia ja tuntemuksia. Kohde asennoituu tutkijaan aina jollakin tavalla. Millä tavalla, se voi olla itse tutkimuksen onnistumiselle haitaksi tai eduksi. Kirjassa on esimerkkejä siitä, miten tutkijan ulkonäkö, siviilisääty, sukupuoli, kansallisuus ja ihonväri tai vaikkapa pukeutuminen vaikuttavat siihen, millaista aineistoa tutkittavat hänelle tarjoavat.

Tutkimuksen aihe vaikuttaa luonnollisesti myös siihen, mikä merkitys tutkijan tietyillä ominaisuuksilla tai oletetuilla ominaisuuksilla on. Millaiselle tutkijalle ja miten puhutaan vaikkapa uskosta, politiikasta, väkivaltakokemuksista, laittomuuksista ja seksuaalisuudesta, määrittää jo paljon tutkimusprosessin etenemistä ja vastaan tulevia ongelmia.

Esimerkiksi Heidi Härkösen kuvaus kuubalaisten seksuaalisuuden tutkimisesta havainnollistaa, miten "tutkijan keho toimii tiedonmuodostuksen alustana". Samalla kaikki etnografisesti tuotettu tieto on vuorovaikutuksen tulosta: vuorovaikutus on väistämättä vaikutusta. Tieto syntyy vain vaikutuksen seurauksena.
Vaikutus alkaa siitä, kun tutkija alkaa "häiritä" tutkittavaa. Tutkija havaitsee, että kehollisilla ominaisuuksillaan hän saa haastateltavan reagoimaan tavalla, jota jonkun toisen tutkijan kohdalla ei tapahtuisi. Tutkija ei voi ollakaan ulkopuolinen tarkkailija. Vaikuttamista välttelevä tarkkailija saattaa jäädä täyttä ymmärrystä vaille.

Tapauskertomukset saavat lukijan pohtimaan niitäkin tutkimuksia, joissa kohteet eivät päästä tutkijaa elämäänsä. Tapauksia on varmaan tuhansittain, alkuunsa tyssänneistä tutkimusyrityksistä vain ei koskaan kirjoiteta sivuakaan. Kenttätyössä haastateltavien tai havainnoitavien hiljaisuus ja puhumattomuus eivät vain estä tiedontuotantoa, ne voivat myös olla viesti. Jos tutkija ei saa haastateltavistaan "mitään irti", se voi olla merkki jostakin todella tärkeästä. Joistakin asioista vaietaan, ja vaitiolo on yhdenlainen, selittämistä vaativa tulos.

Tutkimusprosessi voi saada tutkijan havaitsemaan myös oman muuttumisensa tutkimuksen aikana. Tutkimus saa aikaan jotain sellaista, mihin tutkija ei ole varautunut. Tutkijan ja informantin välinen vuorovaikutus voi muuttaa niin tutkijaa kuin tutkittavaakin. Kenttätyö on vaativaa, ja sen aikana solmitut sosiaaliset suhteet tosiasiallisesti edellyttävät tutkijalta lojaalisuutta tutkittavia kohtaan. Muuten tutkimuksesta ei tule mitään. Lähtökohtaisesti on hyväksyttävä, että tutkija tulee sotkeutuneeksi kohteittensa elämään.

\section{VALTA TUTKIMUKSESSA}

Sen lisäksi, että tutkijan ja kohteen väliset epätasa-arvoiset asetelmat ja niitä koskevat valtasuhteet voivat vaikuttaa ratkaisevasti sekä aineistonkeruuseen että tulkintaan, asioiden käsittely on tutkijalle emotionaalisesti ja eettisesti vaikeaa, kirjoittaa Henni Alava.

Kirjassa on esimerkkejä siitä, miten hierarkkiset rakenteet nousevat tutkimusta tehdessä esiin. Tutkija ei aina pääse tutkittavan kanssa tasavertaisen "episteemisen kumppanin" asemaan luomaan yhteisesti osapuolten lähtökohdat ylittävää ymmärrystä. Tutkija voi joutua tutkittavan välineeksi.

Yhden tapauksen yhteydessä tutkija pohdiskeleekin: "Kertoivatko ihmiset minulle sen, mitä he olettivat minun haluavan kuulla, vai ne asiat, jotka he halusivat minun kuulevan?"

Etnografisesti aineistoa keräävä tutkija joutuu tilanteisiin, joissa hänen on tutkimuksen onnistumisen kannalta välttämätöntä solmia informantteihinsa läheisiä suhteita. Tutkija hyötyy näistä suhteista. Mutta usein tutkittavakin odottaa hyötyvänsä informantin asemastaan. Monet suostuvat tutkimuskohteeksi arvioimalla - ainakin implisiittisesti - tutkimuksen olevan jotenkin hyödyksi asialleen. Tutkijan on hyvä tiedostaa, että tutkimussuhteen toinen osapuoli odottaa saavansa jotain etua tutkimuskohteeksi suostumisesta. On paikallaan olettaa, että tutkittavalla saattaa olla oma agenda, joka ohjaa, mitä hän sanoo ja miten itseään ilmaisee. Voi viedä paljon aikaa 
päästä tuon agendan taakse, vähemmän intressiriippuvaiseen tulkintaan tutkittavan todellisuudesta.

Kirjan kirjoittajat tiedostavat, mitä vaikuttaa se, että he ovat valkoisia, luokka- ja kulttuuritaustaltaan pohjoisten rikkaiden yhteiskuntien menestyjiä yliopistomaailmasta eli yhteiskuntansa tietovaltapyramidin huipulta. Kirjassa kuvataan myös tutkimusta, jossa informanteilla on selvästi enemmän valtaa kuin tutkijalla. Se taas johtaa omanlaiseensa tutkijan ja kohteen väliseen asemaan.

Eija Ranta kirjoittaa Boliviassa tekemistään ministerin haastatteluista: "Kun ministeri ikään kuin omi minut, hänellä oli valta määritellä tiedon tuotanto ja kontrolloida sitä." (s. 47.)

\section{MATKAKERTOMUKSIA JA} AAVISTELUA?

Etnografinen analyysi syntyy "luovana tekona", johon tutkijan persoona ja elämäkerta vaikuttavat, Alava kirjoittaa. Tieto muotoutuu "biografisessa kentässä". Metodologisesti ongelmalliseksi tiedon tekee juuri sen tutkijakohtaisuus. Mutta se ei ole ominaista vain etnografiselle tutkimukselle, vaan ihmistieteisiin usein sisältyy sellaista "näkemyksellisyyttä", jonka varassa tulkinnallinen iso kuva tutkimuskohteesta piirretään.

Samaan aikaan etnografinen lähestymistapa on usein tutkimusongelman vuoksi ainoa mahdollinen tapa saada tietoa tutkimuskohteesta. On paljon tutkimusongelmia, joihin saadaan tolkkua vain menemällä itse paikalle havainnoimaan ja ottamaan selvää. Sen vuoksi on altistettava itsensä vuorovaikutukselle ja kuunneltava, mitä toimijoilla itsellään on sanottavaa.

Etnografinen tieto rakentuu tutkijan ja informantin intersubjektiiviselle ymmärrykselle, mikä näyttäytyy kirjassakin etnografisen tutkimuksen yhtenä vahvuutena. Esimerkiksi monessa survey-tutkimuksessa joutuu kyllä miettimään, miten jaettua lomakkeen laatijan ja vastaajan ymmärrys tutkittavasta kohteesta on.

Tieteellisen tiedon ehtona on toki aina tiedontuotannon läpinäkyvyys: miten ja millaisten oletusten ohjaamana tutkimus on suoritettu, mitä tutkimuksellisia ratkaisuja eri vaiheissa on tehty ja miksi. Etnografinen tutkimus ei edes tavoittele tutkijan ulkopuolisen "todellisuuden" paljastamista ja muotoilua totuudeksi. Siihen tartutaan, koska muillakaan menetelmillä ei ole mahdollista saada kohteesta mielekästä tietoa.

Joissakin tutkimuksissa lukija joutuu miettimään tieteellisen tutkimuksen, matkakertomuksen ja reportaasin eroja. Kysymystä eri tavoin ja eri tarkoituksin tuotetun tiedon eroista olisi ollut tarpeellista kirjassa vielä enemmän. Tieteellinen tutkimus ei ole ainoa tapa tietää, mutta joissakin kohtaa kirjassa paistaa tietämisen sietämätön keveys.

Esimerkiksi Alava kirjoittaa ihan sympaattisesti, että "tietämisen ja todistamisen sijaan tutkijan tehtäväksi jää aistia ja tulkita mahdollisimman herkästi ja refleksiivisesti tutkimiansa ilmiöitä, ihmisiä ja yhteisöitä: kuvata hienovaraisesti ja kunnioittavasti niistä jokin pieni osa, aukkoja ja hämmentyneitä hil- jaisia hetkiä unohtamatta”. (s. 143.) Mutta kun hän kirjoittaa, että "tietämistä paremmin etnografisen tutkimuksen tavoitteeksi sopii aavistelu" (s. 143), päädytään heikoille jäille. Hän ei avaa sen tarkemmin, mitä "aavistelu" oikein on, mutta kovin vähäpätöiseltä se tieteellisen tutkimuksen tavoitteeksi kuulostaa.

Erityisesti näinä totuudenjälkeisinä aikoina tutkimuksen pitäisi haluta tuottaa jotain kestävämpää ja vahvempaa. Aavistelut eivät riitä argumenteiksi.

\section{ETNOGRAFIA EI OLE HELPOIN TIE}

Vaikka ei olisi nimenomaisesti kiinnostunut kuubalaisten perhesuhteista tai anglikaanien ja katolisten politiikkasuhteesta Ugandassa, tutkijoiden reflektiot herättävät tieteellisen tiedon tuottamisesta kiinnostuneen mielenkiinnon.

Pohdinnat ovat harkittuja, ja niistä syntyy koherentti kokonaisuus, mistä tutkijoiden itsensä lisäksi lienee kiittäminen kirjan toimittajia, Jeremy Gouldia ja Katja Uusihakalaa.

Kirja on välttämätöntä luettavaa kaikille etnografista tutkimusta tekeville tai siitä kiinnostuneille. Suosittelen kirjaa haastattelua tutkimusmenetelmänä käyttäville muistutuksena haastattelijan vaikutuksesta keräämäänsä aineistoon. Haastattelija itse on tutkimusväline. Joskus aineistosta tulee kerääjänsä näköinen, tai ehkä pikemminkin sen näköinen, millainen haastattelijan ja haastateltavan välinen kulttuurinen ero on.

\section{HEIKKI SILVENNOINEN}

VTT, professori

Turun yliopisto 